\title{
Recognizing Outstanding Contributions to the Profession: 2000 Honors Reception
}

Richard F. Fenno Jr., Betty Glad, and Samuel C. Patterson were honored with the 2000 Frank J. Goodnow Award for their significant contributions to the political science profession and the American Political Science Association at the 2000 Honors Reception, Wednesday, August 30, in conjunction with the APSA Annual Meeting in Washington, DC. Austin Ranney was selected as a Goodnow Award recipient in recognition of his role as a scholar and leader, but was unable to attend the 2000 Honors Reception. Ranney will receive his Goodnow Award at the 97th Annual Meeting in San Francisco, August 30-September 2, 2001.

Long-regarded as the preeminent student of the U.S. Congress, Richard F. Fenno Jr., was recognized for his scholarship, institutional leadership, and service to the profession.

Fenno's books, such as Home Style, which garnered the APSA's Woodrow Wilson Prize and the D.B. Hardeman Prize from the Lyndon Baines Johnson Library, are based on extraordinary field work. His intellectual influence has been recognized with the Franklin L. Burdette Pi Sigma Alpha best paper award and his election to the National Academy of Sciences and the American Academy of Arts and Sciences. The legislative studies section of the American Political Science Association annually acknowledges his contribution to the study of legislative politics by awarding the Richard $\mathrm{F}$. Fenno Prize for the best book in the field each year. Through his sensitivity to the ethical issues implicit in field work and respect for those he studies, Fenno has set the standard for his students and colleagues. Many of his students have become respected investigators of American national institutions.

Fenno's contribution to the substantive development of political science is matched by his dedication to its institutions, especially his service on college and university committees, on the political science advi- sory panels at both the National Science Foundation and the National Endowment for the Humanities, and on the boards of the Social Science Research Council and the National Election Studies.

Fenno has held many significant offices with APSA, serving as book review editor of the American Political Science Review, chair of the advisory committee of the Congressional Fellowship Program, chair of the Organized Sections Task Force, on numerous award committees, the endowments and constitutional review committees, and as vice president and president of the Association. A hallmark of his presidency was the effort to increase the number of African Americans entering the profession. Fenno was a driving force behind the development of APSA's Ralph Bunche Summer Institute, a fact recognized by the establishment of the Centennial Campaign's Prestage-

Fenno Endowment Fund, which will ensure continuation of APSA's efforts in this area.

Betty Glad was recognized for her contributions to the study of political psychology and for her efforts as a mentor and institution leader.

A founder of the contemporary field of political psychology, Glad's wide-ranging work brings political figures to life and demonstrates how their behavior can and must be understood in light of their personalities. Throughout her career, Glad has carried forward political psychology's concern with pressing national issues, especially war and peace. Her scholarly contributions have been recognized by her colleagues in the discipline and the larger community. In 1997, the International Society of Political Psychology presented Glad with its Harold Lasswell Award for Distinguished Scientific Contributions to Political Psychology. Her 1966 book, Charles Evans Hughes and the Illusions of Innocence, received a Pulitzer Prize nomination.

She has served the profession as an editorial board member of Presidential Studies Quarterly, International Interactions, and Political Psychology; chair of the International Political Science Association's Psycho-Politics Research Group; president of the International Studies Association; vice president and president of the International Society of Political Psychology; and founding member of the Women's Caucus for Political Science. Her commitment to the American Political

Science Association is equally impressive. She has been treasurer, vice president, chair of the Woodrow Wilson Award Committee, and president of the Presidency Research Group. The Women's Caucus for Political Science recognized Glad's dedication to helping individual political scientists by presenting her with its Mentor of Distinction Award in 1989.

Samuel C. Patterson received the Goodnow Award in recognition of his pioneering work in the compara- 
tive legislative field and his service to the profession.

Patterson has contributed significantly to the development of crossnational scholarship, spearheading modern comparative legislative research through his active involvement in a number of early confer-

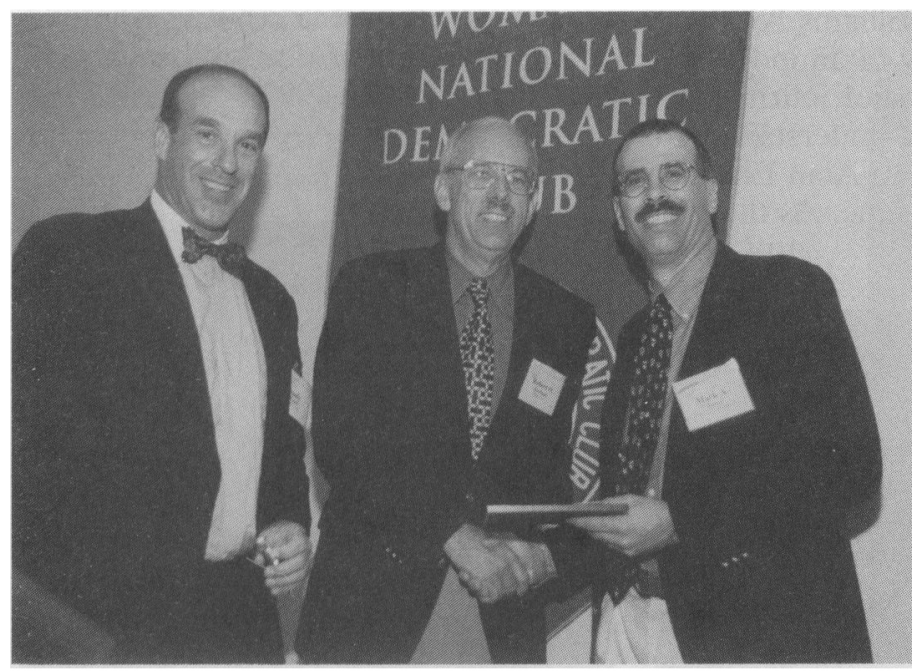

Innovative Teaching. Mark Boyer ( $r$ ), University of Connecticut, accepts the 2000 Rowman \& Littlefield Teaching Award from APSA President Robert $O$. Keohane (center) and Award Chair L. Sandy Maisel. cil member, and as chair of APSA's Committee on Research Support, Woodrow Wilson Award Committee, and Program Committee. He has represented political science in key interdisciplinary organizations as a board member and vice chairman of the Social Science Research

Council and as a council member and chair of the ICPSR.

Throughout his career, Patterson sought to professionalize his students and make them active members of the profession. The assistance he has given young scholars, on large matters and small, has helped scores get started in the profession. given for the first time at the 1997 Annual Meeting. Previous recipients are Gabriel Almond, Walter Beach, Eugene Eidenberg, Doris Graber, Pendleton Herring, Malcolm Jewell, Max Kampelman, Thomas Mann, Warren Miller, Jewel Prestage, and Roberta Sigel.

The Association, and Pi Sigma Alpha, which co-sponsored the reception, also honored political scientists who received campuswide awards for outstanding teaching during the 1999-2000 academic year. More than 150 political scientists received such honors, and out-going APSA President Robert O. Keohane personally recognized those who were able to attend the reception. All winners, including those who could not be there in person to receive them, were given a certificate from Pi Sigma Alpha noting their accomplishment.

Rowman \& Littlefield Publishing Company, which also helped sponsor the reception, established the Rowman \& Littlefield Award for the Innovative Teaching in 1996 to recognize political scientists who have ences. A prolific writer, his research spans the field, from studies of state legislatures and Congress to crossnational work.

Patterson is well known for his exceptional service to the profession as managing editor of the American Political Science Review from 1985 to 1991. He treated the editorship of the discipline's premiere journal as an opportunity to make a contribution to the profession far beyond deciding which articles to publish. He advanced the peer-review system as a seminar by mail for a scholarly discipline, led the effort to establish a discipline-wide style manual, and appealed for quality submissions irrespective of methodology or field. $\mathrm{He}$ is a model of diligence, insight, and fairness.

Patterson is also the exemplar of the good citizen, assuming the role of institution builder in departments, universities, and associations. The founding chair of APSA's legislative studies section, he served on several editorial boards, as an APSA Coun-
The APSA Council established the Frank J. Goodnow Award in 1996 to honor the contributions of individuals to both the development of the political science profession and the building of the Association.

Frank J. Goodnow, the Association's first president, exemplified the public service and volunteerism that this award represents. He was the first of many who voluntarily contributed an extraordinary amount of their time, energy, and attention to building a dynamic learned profession. The Goodnow Award was

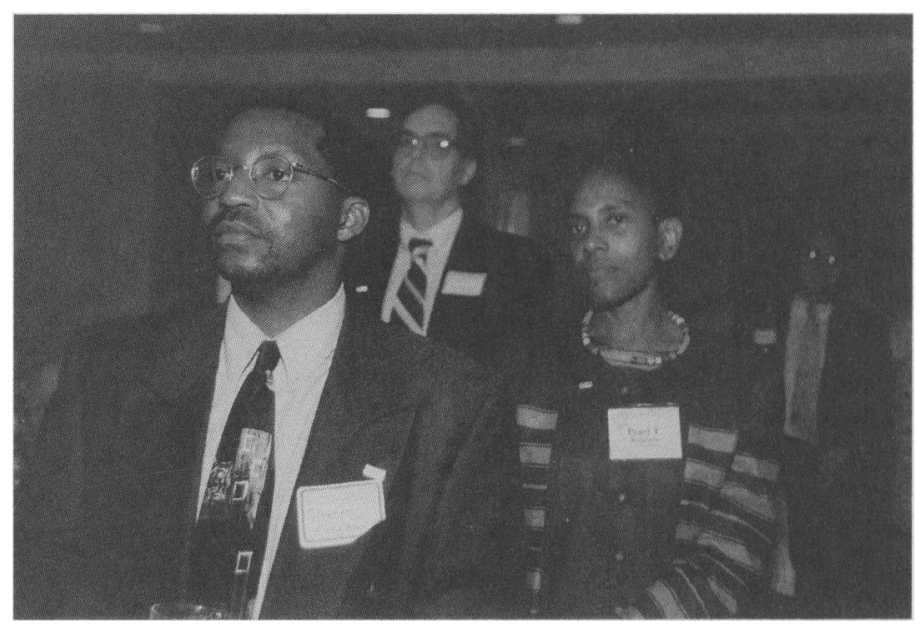

Strength in the classroom. Stephen Ndegwa, College of William \& Mary (foreground), Pearl T. Robinson, Tufts University (middle), and Phil Schrodt, University of Kansas (background-leff) were among the campus wide teaching award winners honored in Washington. developed effective new approaches to teaching. L. Sandy Maisel of Colby College, this year's selection committee chair, presented the award to Mark A. Boyer, University of Connecticut. 